\title{
Evaluation of Political and Regulatory Risks in the Oil Industry
}

\author{
Marcelo Guimaraes ${ }^{1}$ and Andre Carvalhal ${ }^{*}, 2$
}

\author{
${ }^{I}$ Getulio Vargas Foundation, Praia de Botafogo 190, Botafogo, CEP 22250-900, Rio de Janeiro, RJ, Brazil \\ ${ }^{2}$ Federal University of Rio de Janeiro, Rua Pascoal Lemme, 355, Ilha do Fundão, CEP 21941-918, Rio de Janeiro, RJ, \\ Brazil
}

\begin{abstract}
The objective of this study was to determine the best way to quantify the political and regulatory risks in the oil industry. To analyze if these risks should be included in the cash flow or quantified in the WACC (weighted average cost of capital), we used real case studies of exploration and production (E\&P) and refining in Latin America. The oil industry is a good case study for this type of analysis because it is more susceptible to government interventions. Our findings indicate that, in general, changes in oil rules cause only small increases in the country risk and beta (therefore in the WACC) but generate great volatility in the cash flow. Although the political and regulatory risks are considered market risk (i.e. have the potential to affect the whole economy) and should be quantified in the WACC equation, our results indicate that the option to insert these risks directly in the cash flow produce better results when compared to adding a spread in the WACC.
\end{abstract}

Keywords: Political and regulatory risk, Cash flow, WACC, Oil industry.

\section{INTRODUCTION}

In order to determine the value of a particular asset, we usually forecast the cash flows and discount them using the weighted average cost of capital - WACC (Brealey and Myers [1], Damodaran [2], Farber, Gillet and Szafarz [3], and Fernandez [4]). Although this method is simple and very well known, it is very difficult to have reliable assumptions for all variables that affect the expected cash flows of the firm.

Monte Carlo simulation has been vastly used in many applications in finance (Jaeckel [5], Glasserman [6], McLeish [7], Korn, Korn, and Kroisandt [8]) because this method allows us to have variations in the assumptions, assigning different probability distributions for each input variable, which lead to different cash flows and, therefore, different values for the project. In general, a base case and a few scenario analyses are calculated in order to incorporate changes in different variables that affect the cash flows such as prices, sales, market preferences, technologies, government actions, among others. Each scenario leads to different cash flows, which generate a great number of values for project. When all variables change at the same time, the value of the project is even more unpredictable.

Many authors consider that the specific risks of the project (which can be diversified) should be quantified through variations of their assumptions in the cash flow whereas market risks (which cannot be diversified) should be incorporated in the WACC equation (Brealey and Myers [1],

\footnotetext{
*Address correspondence to this author at Federal University of Rio de Janeiro, Rua Pascoal Lemme, 355 - Ilha do Fundão - CEP 21941-918 - Rio de Janeiro - RJ - Brazil; Tel: (5521) 2598-9800;

E-mails: andrec@coppead.ufrj.br, andrecarvalhal@iag.puc-rio.br
}

Damodaran [2], among others), either in the calculation of the beta or in the country risk premium. If we also include market risk in the cash flow, we will double count its effect, because it is already in the discount rate.

The objective of this study was to determine the best way to quantify the political and regulatory risks in the oil industry. To analyze if these risks should be quantified in the WACC equation or should be included in the cash flow through scenario analysis, we used real case studies of exploration and production (E\&P) and refining in Latin America. In order to preserve the confidentiality of the information, we used illustrative values, but adopting rules and dynamics consistent with what happens in Latin America.

When there is government intervention in the economy and potential breach of contract, we consider the country risk as a measure of the risk an investor runs in that place. An increase of risk perception would be represented by an increase in the country risk and in the WACC. In this paper, we analyze if this type of risk can be well represented in the discount rate.

The oil industry is a good case study for this type of analysis because it is more susceptible to government interventions. Even politically stable countries have already changed business conditions and applied anti-market policies in this sector. In general, frequent changes in specific rules cause only small changes in the country risk and beta (therefore in the WACC) but generate great volatility in the cash flow. Although the political and regulatory risks are considered market risk (i.e. have the potential to affect the whole economy) and should be quantified in the WACC equation, our findings indicate that considering these risks in the cash flow produces more consistent results and allows better risk analysis. 
This paper is structured as follows. Section 2 discusses the political and regulatory risks in the oil industry. Section 3 shows the case studies, whereas Section 4 reports the results. Section 5 concludes.

\section{POLITICAL AND REGULATORY RISKS IN THE OIL INDUSTRY}

The oil industry involves different risks such as geological uncertainties, the possibility (or not) of discovery of hydrocarbon, the size of the oil reserves to be explored, among others (Motta et al. [9], Suslick and Schiozer [10], Suslick, Schiozer and Rodriguez [11]). There are also risks common to all other industries, such as the price and cost of the product. Besides these factors, there is the risk of government intervention because of the strategic importance of the sector.

Some of the risks in the oil industry are very hard to measure, especially political risks. It is even more challenging when political, geological and market risks are mixed. This paper analyses these three types of risks and verifies if they should be quantified by adding a spread in the WACC equation and/or by building scenarios in the cash flow estimation. The use of case studies of $\mathrm{E} \& \mathrm{P}$ and refining in Latin America presents real examples of situations where political, geological and market risks are involved and have a huge impact on project valuation.

Two major factors that influence the value of an oil asset are the quantity and the price of the product. Forecasting the size of the oil reserves and for how much the oil will be sold in the next 25 or 30 years is very difficult. Although the prediction of these two factors is not easy, we can use statistics to determine all possible outcomes for each factor and run Monte Carlo simulation to generate results from the combination of them.

There are several studies using Monte Carlo simulation in the evaluation of investment and risks of projects in the oil industry, such as Hailey, Ryan, Barnes, and Woodruff [12], Galli, Armstrong and Jehl [13], Orman and Duggan [14], Motta et al. [9], Razak [15], Suslick and Schiozer [10], Walls [16], Suslick, Schiozer and Rodriguez [11].

The Monte Carlo simulation uses stochastic inputs and outputs data on the cash flow of the project, which facilitate the understanding of the model behavior in various situations. So, instead of making predictions with only the expected value of each risk parameter, we can use all the possibilities, setting higher probability for those values closer to the expected value. For example, we can randomly select 5000 prices and 5000 production curves within limits following statistical criteria, and generate 5000 cash flows that will produce 5000 different net present values (NPV). The average of these $5000 \mathrm{NPVs}$ is the expected monetary value (EMV) of the project.

Erdogan, Mudford, Davidson and Davis [17] show the importance of using stochastic simulation techniques for projects. Through the use of probability distribution for geological, economic and technical parameters and by combining all of them, the mean and variance of the value of the project can be calculated and used for portfolio analysis and optimization.
Rodriguez and Padua [18] provide examples of probability distributions that can be used in different risk inputs (triangular distribution for CAPEX and normal distribution for historical oil prices). They also present a decision tree incorporating geological risk, with a chance of success (generating cash flow through development and production) and with a chance of failure (leading to only a cash flow of capital at risk). The author uses probability distributions for parameters such as production, market price, CAPEX and OPEX, but not for the risk of increased taxes, government royalties or reduction of regulated prices. These factors are in the WACC equation, since the cost of equity incorporates the industry beta and the country premium. Thus, the perception of increased political risk could be represented by adding a spread in the country premium or an increase in the industry beta.

More recently, Arora [19] analyzes different techniques to evaluate risk and uncertainty in upstream oil companies, and Weber [20] shows how to quantify policy risk in energy foresight. Merino [21] analyzes political instability, oil dependence and nationalization of the hydrocarbon sector in some Latin American countries.

It is important to distinguish specific and market risks. The specific risks affect one or a few companies and should not be taken into account by those working with portfolios because they can be eliminated through diversification. However, in this paper, since we are analyzing risks of specific oil projects, most of which cannot be eliminated through diversification, we should quantify these risk in some way.

We consider that the specific risks (those that are unique in the oil industry) will be incorporated in the cash flow (the numerator of the NPV calculation). Market risks, which affect many or all companies, will be incorporated in the WACC (denominator of the NPV calculation).

We first analyze industry-specific risks and try to model statistical distributions for each risk factor. Oil production depends on the size of the reserves, which in general is modeled through a log normal function. In order to simulate the size of a hydrocarbon reserve field that is in the exploratory phase, we estimate Pmean (most likely reserve size equal to the value represented in a deterministic analysis), P10 (minimum reserve size in $90 \%$ of the cases) and P90 (maximum reserve size in $90 \%$ of the cases). These estimates are made through geological studies.

To estimate oil prices we can build econometric models that take into account different factors such as international prices, world demand, substitute products and historical oil prices. These models can be used for forecasting trends and intervals where oil prices may be in the future. Generally, continuous or discrete distributions can be used to simulate oil prices, which will affect the cash flow forecast.

Market risks are treated differently. In theory, regulatory and political risks would be market risks and impact the WACC. However, we observe that changes in specific oil rules seem to generate only small changes in WACC (by increasing the country risk and industry beta), although they can cause significant changes in the cash flows. 
For example, Brazil risk premium (measured by Emerging Markets Bond Index Plus - EMBI) increased a lot in late 2002 (see Table 1), with the uncertainties about the election of a President coming from the worker's party. However, Brazil risk premium remained practically unchanged in the third quarter of 2009 , when there was a huge discussion about the regulatory framework of the presalt oil reserves, including changes in rules for oil blocks that had been tendered by the government to the private sector. Therefore, it seems that political risks are underestimated when we incorporate them in the WACC equation instead of putting them directly in the cash flow.

Table 1. Evolution of Brazil Risk Premium (EMBI)

\begin{tabular}{|c|c|c|c|}
\hline Month & EMBI (bps) & Month & EMBI (bps) \\
\hline \hline jun/02 & 1018 & $\mathrm{mar} / 09$ & 425 \\
\hline $\mathrm{sep} / 02$ & 1881 & $\mathrm{jun} / 09$ & 326 \\
\hline $\mathrm{dec} / 02$ & 1750 & $\mathrm{sep} / 09$ & 253 \\
\hline $\mathrm{mar} / 03$ & 1240 & $\mathrm{dec} / 09$ & 216 \\
\hline jun/03 & 814 & $\mathrm{mar} / 10$ & 205 \\
\hline
\end{tabular}

From now on we present the main political and regulatory risks in the oil industry and discus how they affect the value of oil assets. It is noteworthy that government interference in the oil industry can change almost all items of the cash flow, from the first line (revenues) until the last line (income taxes and dividend distributions).

The revenues, which depend on prices and production, are the first and perhaps the main item affected by political and regulatory risks. For example, in E\&P sharing contracts, the government determines the percentage of the production that belongs to him and the producer gets the rest. The risk is the potential change of this percentage. Other types of revenue risks are related to price control by the government in order to reduce inflation. The government can also set limits for domestic sales and impose barriers to export.

The royalties can be even more unstable. Many countries depend almost exclusively on the oil industry, so an increase in royalties may represent a significant surplus for the government. Recently, a huge increase in royalty rates of gas in Bolivia led to a rise of almost the same magnitude in the revenues of the Bolivian government.

There are also uncertainties that can generate good opportunities. In some countries with governmental interventionism, anti-market policies end up scaring away investors and creating an oil deficit that can only be supplied with imports. This type of solution only has the support of importers if there is a price liberalization (which affects inflation) or a subsidy for the sale by regulated prices (which reduces the government surplus). In many cases, although the government may lose in the beginning, there is no other option but to attract foreign capital with the creation of a pro-market environment. The expectation is that prices be liberalized, which can generate more tax revenues for the government in the future.
With all these possibilities, political and regulatory risks can be measured through different assumptions in the cash flow. We argue that this procedure is more accurate when compared to including these risks in the WACC equation. In this article, we test both methodologies (political and regulatory risk in the WACC and in the cash flow) in E\&P and refining cases studies.

With the help of @risk, we run Monte Carlo simulations and compare the expected monetary value (EMV, equivalent to the average of NPVs obtained in Monte Carlo simulation) and value at risk (VAR, equivalent to the maximum loss with $95 \%$ probability) using both methods.

Although EMV is an established standard approach for assessing project value, it does not take into consideration the entire risk to investors caused by uncertainty about future cash flow. Haimes [22] and Smith [23] point out that EMV is not an adequate measure, because the distribution of value is so broad and so skewed that no central measure represents it adequately.

Utility theory provides a further measure by taking account of individuals' perceptions of gains and losses. The principle of expected utility maximization states that a rational investor acts to select an investment which maximizes his expected utility of wealth. Friedman and Savage [24] argue that utility theory is superior to EMV because it offers an approach for incorporating risk factor consistently.

To implement the expected utility approach, it is necessary to determine a utility function. Both theory and practical experience have shown that the exponential utility function is appropriate in decision analysis (Buhlmann [25] and Wang [26]). For risk-averse decision-makers this function has the following form:

$u(x)=1-\exp (-\alpha x)$

where $u(x)$ represents the utility function, $x$ is the evaluation measure (NPVs in US\$ billion in this paper), and $\alpha$ represents the degree of risk aversion.

Since it is difficult to identify the parameter $\alpha$ in real-life situations, we assume $\alpha=0.5$. We also test $\alpha=1.5$ to represent more risk-averse decision-makers. Finally we use the calculated values of utility to estimate expected utility value (EUV) adopting the same procedure that was performed to calculate EMV.

We create different cash flow scenarios for changes in regulated oil prices and government stakes in the production without changing the WACC. Then we simulate the cash flows keeping prices and government stakes fixed but using a higher WACC. Finally, we compare the effects of each methodology (political and regulatory risk in the WACC and in the cash flow), so that we can choose the most appropriate model.

To determine the increase in the WACC due to political and regulatory risks, we use a few parameters to calibrate our models. We argue that the perception of political and regulatory risks would increase WACC via an increase in the cost of equity through a higher country risk premium. We can represent WACC as the weighted average cost of capital:

$W A C C=K e^{*}(E / V)+K d *(D / V)$ 
where $\mathrm{Ke}$ is the cost of equity, $\mathrm{Kd}$ is the after-tax cost of debt, $\mathrm{V}$ is the firm value, $\mathrm{E}$ is the equity value, and $\mathrm{D}$ is the debt value, respectively. The cost of equity can be obtained by the CAPM (Capital Asset Pricing Model) from the following equation:

$K e=R f+\beta(R m-R f)+$ CountryRisk

where $\mathrm{Rf}$ is risk-free rate of return, $\beta$ is the market risk of the sector, $\mathrm{Rm}$ is the market return, and CountryRisk is the premium that the country's debt pay above the US Treasury.

Suppose there is a company with a moderate capital structure $(30 \%$ equity and $70 \%$ debt) in a very risky country (EMBI of $10 \%$ ). If there is a significant increase of $20 \%$ in the country risk (EMBI rising to $12 \%$ ), because of higher political and regulatory risks, WACC will increase only $0.6 \%$. For the WACC to increase $2 \%$, EMBI should climb almost $70 \%$. If the country is less risky (EMBI of $3 \%$ ), EMBI needs to climb over $300 \%$ to produce a WACC increase of $2 \%$. In this paper, we use a $2 \%$ increase in WACC to represent the political and regulatory risks. As we can see from the above analysis, this number is quite conservative.

\section{CASE STUDIES IN THE OIL INDUSTRY}

This section presents the case studies in the oil industry used to analyze if political and regulatory risks should be quantified in the WACC equation or should be included in the cash flow through scenario analysis. We study projects of Exploration and Production (E\&P) and Refining. These projects are real and happened in Latin America. In order to preserve the confidentiality of the information, we use illustrative values, but using rules and dynamics consistent with what happens in Latin America.

It is important to note that, although the projects are based on case studies, our models and assumptions are similar to other studies in the oil industry (Hailey, Ryan, Barnes, and Woodruff [12], Galli, Armstrong and Jehl [13], Orman and Duggan [14], Motta et al. [9], Razak [15], Suslick and Schiozer [10], Walls [16], Suslick, Schiozer and Rodriguez [11], Arora [19], and Weber [20]).

\subsection{Exploration \& Production}

First, we study the impact of E\&P business, specifically in exploration, analyzing two types of risks: regulation of oil prices and changes in oil royalties. There are four distinct sequential phases in the E\&P business (exploration, assessment, development and production). The exploratory phase is related to seismic expenditures for oil mapping and drilling in order to search for oil. At this moment the capital is at risk, because there will be no financial return if there is no oil. The assessment phase occurs only after the discovery of hydrocarbons. It is the period in which there are studies to determine the oil type and the size of the reserve in order to decide if the asset is economically viable. In case of economical feasibility, we move to the development phase, which corresponds to more than $80 \%$ of total investments, because it involves not only the production but also the construction of facilities. Table 2 shows the assumptions used in our E\&P model, which are based on case studies in Latin America.
It is noteworthy that the royalty is a sort of compensation paid by the producer to the government. We run simulations with an initial royalty of $15 \%$ over revenues. The type of oil is WTI, a light oil that has its price quoted on the New York Stock Exchange. We assume a constant price of US\$ 60/bbl (price per barrel) as base case. We model the following types of risks in order to have a more detailed analysis:

- Price risk: triangular distribution with parameters $+80 \%$ and $-80 \%$ over the base case (US\$ 60/bbl);

- Production risk: triangular distribution with parameters $+20 \%$ and $-20 \%$ over the base case;

- Royalty risk: discrete distribution with $80 \%$ chance that the royalty rate is $15 \%$ and $20 \%$ chance that the royalty rate increases to $80 \%$;

- Capex and Opex risk: triangular distribution with parameters $-10 \%, 0 \%$ and $10 \%$ over the base case.

We set the probability of finding hydrocarbons (known as the "probability of success") at $20 \%$. It is an assumption of extreme importance, because the cash flow after investment depends on the success in the exploratory phase. Appendix A shows the details of the E\&P model adopted in this paper.

Table 2. Assumptions of E\&P Model

\begin{tabular}{|c|c|c|}
\hline Variable & Period & Value \\
\hline \hline Exploration phase & Year 1 & US\$ 200 MM \\
\hline Assessment phase & Year 2 & US\$ 400 MM \\
\hline Development phase & Year 3 to 6 & US\$ 3,400 MM \\
\hline Reserves & From year 7 on & $300 \mathrm{MM} \mathrm{barrels}$ \\
\hline Royalties & Production phase & $15 \%$ revenue \\
\hline Income tax & Production phase & $34 \%$ income \\
\hline
\end{tabular}

\subsection{Refining}

We use a hypothetical refinery capable of processing 100,000 barrels per day (bpd), and working with $90 \%$ capacity $(90,000 \mathrm{bdp})$. We assume that all the products are sold domestically, where oil prices are set at US\$ 40/bbl and the refined barrel can be sold for US\$ 45/bbl.

When the domestic demand increases, the refinery is required to produce $100,000 \mathrm{bpd}$. In our scenario, however, there is no domestic surplus of oil and the refinery needs to import. Thus, the additional 10,000 bdp are purchased at market price (US\$ 80/bbl), generating a negative margin, because the refined barrel is still sold for US\$ 45/bbl. Table 3 shows the assumptions used in our refining model.

We model the following types of risks in order to have a more detailed analysis:

- Input price risk: we use two scenarios: i) $90,000 \mathrm{bpd}$ bought for US\$ 40/bbl and ii) 90,000 bpd bought for US\$ 40/bbl and 10,000 bpd for US\$ 80/bbl;

- Capex and Opex risk: triangular distribution with parameters $-10 \%, 0 \%$ and $10 \%$ over the base case. 
Appendix $\mathbf{B}$ shows the details of the refining model adopted in this paper.

Table 3. Assumptions of Refining Model

\begin{tabular}{|c|c|}
\hline Variable & Base Case \\
\hline \hline Capacity & $100,000 \mathrm{bpd}$ \\
\hline Production & $90,000 \mathrm{bpd}$ \\
\hline Price of domestic oil & US\$ 40/ bbl \\
\hline Price of imported oil & US\$ 80/ bbl \\
\hline Price of refined barrel & US\$ 45/ bbl \\
\hline Total investment & US\$ 200 MM \\
\hline Capex per annum & US\$ 20 MM \\
\hline Fixed Opex per annum & US\$ $100 \mathrm{MM}$ \\
\hline Variable Opex per annum & US\$ 3 MM/bbl \\
\hline Income tax & $34 \%$ income \\
\hline
\end{tabular}

\section{EMPIRICAL RESULTS}

\subsection{Price Controls in E\&P}

Since oil is a commodity, its price is fixed internationally. Brent (in England) and WTI (in the USA) guide the oil market serving as parameters. The international trading of oil causes prices to become even more unpredictable, as the prices go well beyond the laws of supply and demand, having a great component of speculative factors. Because of the volatility of oil prices and its influence on public accounts and economic indicators, the government of many countries generally intervenes in the oil market, setting limits for domestic oil prices.

The government of a few countries, those with a better fiscal situation, may give subsidies to domestic producers in order to compensate for their loss (difference between internal and external prices). In general, control of domestic prices is accompanied by restrictions on exports, which end up leaving the producer with no way out, but to sell the oil on the domestic market for a price much lower than that in the international market. The situation of the producer gets worse in times of economic growth, not only because the differences in oil prices are more pronounced, but also because production costs increase.

Our models simulate such risk. The idea is to do an exercise showing the variation of the value of E\&P assets when we receive information that the market will be regulated. We first let prices fluctuate within a triangular distribution, in which they rise or fall by up to $80 \%$ of original value (base case). Then we calculate the value of E\&P assets with the new risk using two models: i) limiting the price at US\$ 40/bbl in the cash flow; (ii) using market prices in the cash flow and increasing the WACC by $2 \%$. Table 4 shows the results of both methods.

As expected, EMV and EUV drop significantly using price limits in the cash flow. However, there is only a little change when we increase WACC, which is not consistent with the effective impact caused by price controls. Further, VAR is higher when price limits are incorporated in the cash flow when compared to a WACC increase. It is important to note that an increase of WACC by $2 \%$ is very huge (see Section 2), and even with a substantially higher cost of capital, EMV and EUV seem overestimated, and VAR is underestimated.

Table 4. Results for Price Controls in E\&P (in US\$ MM)

\begin{tabular}{|c|c|c|c|}
\hline Variable & $\begin{array}{c}\text { No Political and } \\
\text { Regulatory Risks }\end{array}$ & $\begin{array}{c}\text { Price Limit in } \\
\text { the Cash Flow }\end{array}$ & $\begin{array}{c}\text { WACC } \\
\text { Increase }\end{array}$ \\
\hline \hline EMV & $1,025.84$ & 1.53 & 822.27 \\
\hline VAR & -99.41 & -157.44 & -130.38 \\
\hline EUV $(\alpha=0.5)$ & 0.36 & 0.00 & 0.31 \\
\hline EUV $(\alpha=1.5)$ & 0.65 & -0.01 & 0.58 \\
\hline
\end{tabular}

We also run a sensitivity analysis and the results (not reported but available upon request) indicate that oil prices present the highest risk, causing EMV to range from US\$ 585.26 to $3,220.12$ million, and EUV $(\alpha=0.5)$ from -0.34 to 0.80 .

\subsection{Nationalism in E\&P via Increased Royalties}

In recent years, a few Latin American economies have elected nationalist individuals to govern the countries. A key element of the nationalism movement is the ownership of oil assets and of the production factors related to the oil industry. The two most common facts that have happened in many countries are the increase of royalties and expropriation of assets.

The royalties are taxes on oil production. In many countries royalties are paid in barrels of oil (instead of cash). Although there is not much financial difference between the two forms, the first case implies that part of the production belongs to the government. As production rates and reserves are taken into account by investors, the fact that the oil is owned by the government ends up creating a disadvantage to companies that cannot compute part of the production in their financial statements. Moreover, since the government owns part of the production, it has autonomy and flexibility to sell the oil barrels coming from royalties in the market, which can affect supply and prices.

In fact, regardless of how royalties are paid (in barrels or cash), companies hope that royalties rates do not change after the signing of the contract. However, in many countries, especially those with radical changes of government, the increase of royalties in the oil industry is very common. The variation of royalties is a major risk in the oil industry.

The trap is that E\&P contracts generally make reference to a law that contains the royalty rate, which gives more freedom to the government, because they can change the rate without breaking contracts. We use a discrete distribution with $80 \%$ chance that the royalty rate is $15 \%$ and $20 \%$ chance that the royalty rate increases to $80 \%$. Table $\mathbf{5}$ shows the results for the cash flow and for the increase of WACC.

We can see that EMV and EUV drop more in the cash flow than in the WACC model. The decrease is smaller than the previous case, suggesting that price controls can generate 
higher losses than changes in royalties. The VAR analysis indicates that the risk is much higher when royalty changes are incorporated in the cash flow when compared to a WACC increase. It is worth noting that the VAR for royalty changes is higher than for price controls. Thus, the expected monetary and utility values and the risk associated with E\&P assets are higher for royalty changes than price limits.

Table 5. Results for Nationalism in E\&P via Increased Royalties (in US\$ MM)

\begin{tabular}{|c|c|c|c|}
\hline Variable & $\begin{array}{c}\text { No Political and } \\
\text { Regulatory Risks }\end{array}$ & $\begin{array}{c}\text { Increased Royalties } \\
\text { in the Cash Flow }\end{array}$ & $\begin{array}{c}\text { WACC } \\
\text { Increase }\end{array}$ \\
\hline \hline EMV & $1,015.32$ & 723.98 & 814.08 \\
\hline VAR & -92.97 & -611.55 & -152.16 \\
\hline EUV $(\alpha=0.5)$ & 0.36 & 0.24 & 0.31 \\
\hline EUV $(\alpha=1.5)$ & 0.64 & 0.28 & 0.58 \\
\hline
\end{tabular}

The sensitivity analysis reveals that oil price is the factor with the highest risk. EMV can range from US\$ -601.34 to $3,026.21$ million, while EUV $(\alpha=0.5)$ varies from -0.35 to 0.78 .

\subsection{Nationalism in E\&P via Expropriation}

The expropriation of assets is even more extreme than an increase in royalties. There are recent examples in Latin America in both E\&P and refining. In some cases, the governments have a legal basis for the expropriation. The question is how much the government should pay for the nationalized assets. The price can be a partial or full recovery of the investments already made (which often does not pay for the risks), but can also be the discounted cash flow over the remaining life of the asset (where the controversy ends up being the assumptions used in the analysis).

One way to include this risk in the cash flow would be to stop the project in a year following a election, which would represent the beginning of the mandate of a more extreme government. We need to set a probability of a particular election result lead to nationalization, which can be proxied by the probability of nationalist candidate winning the election. Then, the value to be paid by government due to expropriation could be the value of investments not depreciated or the NPV of the future cash flow.

The risk of expropriation is the greatest example of a political risk. While rising oil prices, market regulation, royalty changes, price control, mandatory supply are related specifically to the oil sector, the nationalization of businesses is considered a market risk, and is generally quantified in the WACC equation. Therefore, we opt not to compare the inclusion of this risk in the cash flow because it is already reflected in the cost of capital.

\subsection{Refining Risk via Lack of Supply}

A policy of price control has the purpose to sell the products to consumers for a low price. It can be due to social issues (since oil and its products are also consumed by poor people), political issues (higher probability of gaining votes for the next election) or economic issues (control inflation). This policy affects the whole oil supply chain.
The first side effect is the lack of incentives to the producer at the beginning of the chain. The refiner, which usually has the obligation to supply the domestic market, suffers when there is lack of oil. That leaves him with two options: import crude oil or refined products. Anyway, the extra cost falls on him, especially when the government has no budget to give subsidies. The consequence to the refiner can be severe.

Suppose there is a ceiling price at US\$ $42 / \mathrm{bbl}$ in a country. If a refiner has a margin of US $\$ 5 / \mathrm{bbl}$, the size of the loss will be big if he has to buy it for US\$ $80 / \mathrm{bbl}$ in the international market. Another option for the refiner would be to import the refined product and sell it immediately to the distributor with a negative margin.

Returning to our case, we assume a refinery (with capacity of $100,000 \mathrm{bpd}$ ) that produces $90,000 \mathrm{bpd}$. This refinery is established in a country with price controls, buys oil for US\$ 40/bbl and has a margin of US\$ $5 / \mathrm{bbl}$. If the demand goes up, it must feed it by law, increasing its production to $100,000 \mathrm{bpd}$. The problem is that, as there is no excess of oil internally, he would need to import at market prices.

We analyze the risk of lack of input due to increased demand by assuming that the refinery is obliged to import 10,000 bpd at market prices. The lack of input could also be caused by decreased domestic production because of price limits imposed by the government. The consequence would be the same, with the refiner being forced to import oil, refine and sell it with negative margin.

We assume that the demand will be $90,000 \mathrm{bpd}$ at US\$ $40 / \mathrm{bbl}$ in $80 \%$ of the cases. In the remaining $20 \%$ of the cases, the demand will be $100,000 \mathrm{bpd}$, and the refinery has to buy $10,000 \mathrm{bpd}$ for US $\$ 80 / \mathrm{bbl}$. The refined barrel can be sold for US\$ 45/bbl, which generates a margin of US\$ 5/bbl in case of purchase for US\$ 40/bbl and US\$ $-35 / \mathrm{bbl}$ in case of purchase for US\$ 80/bbl. Table 6 shows the results for the cash flow model and for the increase of WACC.

Table 6. Results for Refining Risk via Lack of Supply (in US\$ MM)

\begin{tabular}{|c|c|c|c|}
\hline Variable & $\begin{array}{c}\text { No Political and } \\
\text { Regulatory Risks }\end{array}$ & $\begin{array}{c}\text { Refining Risk } \\
\text { in the Cash Flow }\end{array}$ & $\begin{array}{c}\text { WACC } \\
\text { Increase }\end{array}$ \\
\hline \hline EMV & 348.67 & -266.21 & 314.26 \\
\hline VAR & 204.41 & -837.00 & 186.54 \\
\hline EUV $(\alpha=0.5)$ & 0.16 & -0.16 & 0.14 \\
\hline EUV $(\alpha=1.5)$ & 0.40 & -0.70 & 0.37 \\
\hline
\end{tabular}

Similar to the previous analysis, EMV and EUV drop significantly incorporating the refining risk in the cash flow, and there is only a little change when we increase WACC. This small decrease of EMV and EUV is not consistent with the real impact caused by refining risks originated by lack of supply. The risk (VAR) is much higher when refining risks are incorporated in the cash flow when compared to a WACC increase. The EMV, EUV and VAR under a WACC increase do not change significantly when compared to the situation without political and regulatory risks. 


\section{APPENDIX A}

\section{E\&P Model}

\begin{tabular}{|c|c|c|c|c|c|c|c|c|c|c|c|c|c|c|c|c|c|c|c|c|c|c|c|}
\hline VARIABLE & UNITS & FIXED & 2011 & 2012 & 2013 & 2014 & 2015 & 2016 & 2017 & 2018 & 2019 & 2020 & 2021 & 2022 & 2023 & 2024 & 2025 & 2026 & 2027 & 2028 & 2029 & 2030 & 2031 \\
\hline \multicolumn{24}{|l|}{ INPUTS } \\
\hline Oil Price (WTI) & US\$/Bbl & & 80.00 & 80.00 & 80.00 & 80.00 & 80.00 & 80.00 & 80.00 & 80.00 & 80.00 & 80.00 & 80.00 & 80.00 & 80.00 & 80.00 & 80.00 & 80.00 & 80.00 & 80.00 & 80.00 & 80.00 & 80.00 \\
\hline Oil Production & MM Bы & & & & & & & & 48.50 & 58.89 & 62.36 & 41.57 & 24.25 & 13.86 & 10.39 & 693 & 6.93 & 5.20 & 4.85 & 4.50 & 4.16 & 3.81 & 3.81 \\
\hline CAPEX Exploration & MM US\$ & & $\mid 200.00$ & & & & & & & & & & & & & & & & & & & & \\
\hline CAPEX Appraisal & MMUS\$ & & & 400.00 & & & & & & & & & & & & & & & & & & & \\
\hline CAPEX Development & MM US\$ & & & & 900.00 & 1440.00 & 900.00 & 360.00 & & & & & & & & & & & & & & 200.00 & 200.00 \\
\hline OPEX & MM US\$ & & & & & & & & 150.00 & \begin{tabular}{|l|}
150.00 \\
\end{tabular} & \begin{tabular}{|l|}
150.00 \\
\end{tabular} & 150.00 & 150.00 & 150.00 & \begin{tabular}{|l|}
150.00 \\
\end{tabular} & 150.00 & 150.00 & 150.00 & 150.00 & 150.00 & 150.00 & 150.00 & 150.00 \\
\hline Depreciation & $\%$ & $10 \%$ & & & & & & & & & & & & & & & & & & & & & \\
\hline Royalty & $\%$ & $15 \%$ & & & & & & & & & & & & & & & & & & & & & \\
\hline Income Tax & $\%$ & $34 \%$ & & & & & & & & & & & & & & & & & & & & & \\
\hline WACC & $\%$ & $12 \%$ & & & & & & & & & & & & & & & & & & & & & \\
\hline Success Prob & $\%$ & $20 \%$ & & & & & & & & & & & & & & & & & & & & & \\
\hline & & & & & & & & & & & & & & & & & & & & & & & \\
\hline \multirow[t]{2}{*}{ RISK INPUTS } & & & \multicolumn{3}{|c|}{$\%$ Range } & \multicolumn{2}{|c|}{ Rate } & \multicolumn{2}{|c|}{ Probability } & & & & & & & & & & & & & & \\
\hline & & & Minimum & Mean & Maximum & Old & New & Old & New & & & & & & & & & & & & & & \\
\hline Price Range & $\%$ & 0,00 & -0.8 & 0 & 0.8 & & & & & & & & & & & & & & & & & & \\
\hline Production Range & $\%$ & 0,00 & -0.20 & 0 & 0.20 & & & & & & & & & & & & & & & & & & \\
\hline Overbudget CAPEX & $\%$ & 0,00 & -0.1 & 0 & 0.1 & & & & & & & & & & & & & & & & & & \\
\hline Overbudget OPEX & $\%$ & 0,00 & -0.1 & 0 & 0.1 & & & & & & & & & & & & & & & & & & \\
\hline Royalty & $\%$ & 0,15 & & & & 0.15 & 0.80 & 1 & 0 & & & & & & & & & & & & & & \\
\hline Price Limit-Regulat. & US\$/Bbl & 2000 & & & & & & & & & & & & & & & & & & & & & \\
\hline WACC (Spread) & $\%$ & & & $0 \%$ & & & & & & & & & & & & & & & & & & & \\
\hline & & & & & & & & & & & & & & & & & & & & & & & \\
\hline \multicolumn{24}{|l|}{ CALCULATION } \\
\hline Price & US\$/Bbl & & 80 & 80 & 80 & 80 & 80 & 80 & 80 & 80 & 80 & 80 & 80 & 80 & 80 & 80 & 80 & 80 & 80 & 80 & 80 & 80 & 80 \\
\hline Revenue & MMUS\$ & & 0.00 & 0.00 & 0.00 & 0.00 & 0.00 & 0.00 & $|3,879.91|$ & $4,711.32$ & $4,988.45$ & 3.325 .641 & 1.939 .95 & 1.108 .55 & 831.41 & 554.27 & 554.27 & $|415.70|$ & 387.99 & 360.28 & 332.56 & 304.85 & 304.85 \\
\hline Royalties & MM US\$ & & 0.00 & 0.00 & 0.00 & 0.00 & 0.00 & 0.00 & 581.99 & 706.70 & 748.27 & 498.85 & 290.99 & 166.28 & 124.71 & 83.14 & 83.14 & 62.36 & 58.20 & 54.04 & 49.88 & 45.73 & 45.73 \\
\hline Total Capex & MM US\$ & & 200.00 & 400.00 & 900.00 & $1,440.00$ & 900.00 & 360.00 & 0.00 & 0.00 & 0.00 & 0.00 & 0.00 & 0.00 & 0.00 & 0.00 & 0.00 & 0.00 & 0.00 & 0.00 & 0.00 & 200.00 & 200.00 \\
\hline Total Opex & MMUS\$ & & 0.00 & 0.00 & 0.00 & 0.00 & 0.00 & 0.00 & 150.00 & 150.00 & 150.00 & 150.00 & 150.00 & 150.00 & \begin{tabular}{|l|l|}
150.00 \\
\end{tabular} & 150.00 & 150.00 & 150.00 & 150.00 & 150.00 & 150.00 & 150.00 & 150.00 \\
\hline Base of Depreciation & MM US\$ & & 200.00 & 600.00 & $1,500.00$ & $2,940.00$ & $3,840.00$ & $4,200.00 \mid 4$ & $|4,200.00|$ & $3,780.00^{3}$ & $3,360.00 \mid 2$ & $2,\left.940.00\right|_{2}$ & $|2,520.00| 2$ & $2,100.00 \mid$ & $1,680.00 \mid 1$ & $1,260.00$ & 840.00 & 420.00 & 0.00 & 0.00 & 0.00 & 200.00 & -20.00 \\
\hline Depreciation & MM US\$ & & 0.00 & 0.00 & 0.00 & 0.00 & 0.00 & 0.00 & 420.00 & 420.00 & 420.00 & 420.00 & 420.00 & 420.00 & 420.00 & 420.00 & 420.00 & 420.00 & 0.00 & 0.00 & 0.00 & 420.00 & 0.00 \\
\hline & & & & & & & & & & & & & & & & & & & & & & & \\
\hline \multicolumn{24}{|l|}{ CASH FLOW } \\
\hline \multicolumn{24}{|l|}{ Revenue } \\
\hline Royalties & MM US\$ & & 0.00 & 0.00 & 0.00 & 0.00 & 0.00 & 0.00 & $3,879.91$ & $4,711.32$ & $\mid 4,988.45$ & 3.325 .641 & $\mid 1,939.95$ & $1,108.55$ & 831.41 & 554.27 & 554.27 & $|415.70| 3$ & 387.99 & 360.28 & 332.56 & 304.85 & 304.85 \\
\hline Opex & MM US\$ & & 0.00 & 0.00 & 0.00 & 0.00 & 0.00 & 0.00 & -581.99 & -706.70 & -748.27 & -498.85 & -290.99 & -166.28 & -124.71 & \begin{tabular}{|c|}
$\mid-83.14$ \\
\end{tabular} & -83.14 & -62.36 & -58.20 & -54.04 & -49.88 & -45.73 & -45.73 \\
\hline EBITDA & MM US\$ & & 0.00 & 0.00 & 0.00 & 0.00 & 0.00 & 0.00 & -150.00 & -150.00 & -150.00 & -150.00 & -150.00 & -150.00 & -150.00 & -150.00 & $-150.00 \mid$ & $|-150.00|-$ & -150.00 & -150.00 & -150.00 & $\mid-150.00$ & -150.00 \\
\hline Depreciation & MM USS & & 0.00 & 0.00 & 0.00 & 0.00 & 0.00 & 0.00 & $3,147.92$ & $3,854.62$ & $4,090.18$ & $2,676.79$ & $1,498.96$ & 792.26 & \begin{tabular}{|l|}
556.70 \\
\end{tabular} & |321.13 & 321.13 & 203.35 & 179.79 & 156.24 & 132.68 & 109.12 & 109.12 \\
\hline EBITDA & MM US\$ & & 0.00 & 0.00 & 0.00 & 0.00 & 0.00 & 0.00 & -420.00 & -420.00 & -420.00 & -420.00 & -420.00 & -420.00 & -420.00 & -420.00 & -420.00 & $-420.00 \mid$ & 0.00 & 0.00 & 0.00 & $\mid-420.00$ & 0.00 \\
\hline Depreciation & MM USS & & 0.00 & 0.00 & 0.00 & 0.00 & 0.00 & 0.00 & $|2,727.92| 3$ & 3,434.62 & \begin{tabular}{|c|c|c|}
$3,670.18$ & \\
\end{tabular} & $2,256.79 \mid 1$ & $1,078.96$ & 372.26 & \begin{tabular}{|l|l|}
136.70 \\
\end{tabular} & -98.87 & -98.87 & $|-216.65|$ & $\mid 179.79$ & 156.24 & 132.68 & $\mid-310.88$ & 109.12 \\
\hline Tax & MM US\$ & & 0.00 & 0.00 & 0.00 & 0.00 & 0.00 & 0.00 & 420.00 & 420.00 & 420.00 & 420.00 & 420.00 & 420.00 & 420.00 & 420.00 & 420.00 & 420.00 & 0.00 & 0.00 & 0.00 & 420.00 & 0.00 \\
\hline Working Capital & MMUS\$ & & 0.00 & 0.00 & 0.00 & 0.00 & 0.00 & 0.00 & 927.49 & 1.167 .77 & $1,247.86$ & 767.31 & 366.85 & 126.57 & 46.48 & 0.00 & 0.00 & \begin{tabular}{|l|}
0.00 \\
\end{tabular} & 61.13 & 53.12 & 45.11 & 0.00 & 37.10 \\
\hline CASH FLOW Op & MM US\$ & & & & & & & & & & & & & & & & & & & & & & \\
\hline Investiments & MMUSs & & 0.00 & 0.00 & 0.00 & 0.00 & 0.00 & 0.00 & $|4,075.41|:$ & $|5,022,39|$ & 5338.05 & $3,444.101$ & 1,86581 & 918.83 & \begin{tabular}{|c|}
603.17 \\
\end{tabular} & 321.13 & 321.13 & 20335 & 240.92 & 20936 & 177.79 & 109.12 & 146.22 \\
\hline CASH FLOW & MM US\$ & & -200.00 & -400.00 & -900.00 & $-1,440.00$ & -900.00 & $\mid-360.00$ & 0.00 & 0.00 & 0.00 & 0.00 & 0.00 & 0.00 & 0.00 & 0.00 & 0.00 & \begin{tabular}{|l|}
0.00 \\
\end{tabular} & 0.00 & 0.00 & 0.00 & -200.00 & -200.00 \\
\hline & & & & & & & & & & & & & & & & & & & & & & & \\
\hline NPV & MM USS & & $5,931.65$ & & & & & & & & & & & & & & & & & & & & \\
\hline Exploration & MM USs & & $(200.00)$ & & & & & & & & & & & & & & & & & & & & \\
\hline Sucess & $\%$ & & $20 \%$ & & & & & & & & & & & & & & & & & & & & \\
\hline EMV & MM USs & & 1,02633 & & & & & & & & & & & & & & & & & & & & \\
\hline
\end{tabular}




\section{APPENDIX B}

\section{Refining Model}

\begin{tabular}{|c|c|c|c|c|c|c|c|c|c|c|c|c|c|c|c|c|c|c|c|c|c|c|c|}
\hline Variable & UNIts & FIXED & 2011 & 2012 & 2013 & 2014 & 2015 & 2016 & 2017 & 2018 & 2019 & 2020 & 2021 & 2022 & 2023 & 2024 & 2025 & 2026 & 2027 & 2028 & 2029 & 2030 & 2031 \\
\hline \multicolumn{24}{|l|}{ INPUTS } \\
\hline Refinery Capacity & MBbl & & 100 & 100 & 100 & 100 & 100 & 100 & 100 & 100 & 100 & 100 & 100 & 100 & 100 & 100 & 100 & 100 & 100 & 100 & 100 & 100 & 100 \\
\hline Domestic Oil (Best profit) & $\%$ & & 90 & 90 & 90 & 90 & 90 & 90 & 90 & 90 & 90 & 90 & 90 & 90 & 90 & 90 & 90 & 90 & 90 & 90 & 90 & 90 & 90 \\
\hline Domestic Oil Price & $\mathrm{U} \$ / \mathrm{Bbl}$ & & 40 & 40 & 40 & 40 & 40 & 40 & 40 & 40 & 40 & 40 & 40 & 40 & 40 & 40 & 40 & 40 & 40 & 40 & 40 & 40 & 40 \\
\hline Intemational oil Price & $\mathrm{US} / \mathrm{Bbl}$ & & 80 & 80 & 80 & 80 & 80 & 80 & 80 & 80 & 80 & 80 & 80 & 80 & 80 & 80 & 80 & 80 & 80 & 80 & 80 & 80 & 80 \\
\hline Refined Price & US/Bbl & & 45 & 45 & 45 & 45 & 45 & 45 & 45 & 45 & 45 & 45 & 45 & 45 & 45 & 45 & 45 & 45 & 45 & 45 & 45 & 45 & 45 \\
\hline CAPEX Accrued & MM US\$ & 200 & & & & & & & & & & & & & & & & & & & & & \\
\hline CAPEX & MM US\$ & & 20.00 & 20.00 & 20.00 & 20.00 & 20.00 & 20.00 & 20.00 & 20.00 & 20.00 & 20.00 & 20.00 & 20.00 & 20.00 & 20.00 & 20.00 & 20.00 & 20.00 & 20.00 & 20.00 & 20.00 & 20.00 \\
\hline Overhead OPEX & MM US\$ & & 100.00 & 100.00 & 100.00 & 100.00 & 100.00 & 100.00 & 100.00 & 100.00 & 100.00 & 100.00 & 100.00 & 100.00 & 100.00 & 100.00 & 100.00 & 100.00 & 100.00 & 100.00 & 100.00 & 100.00 & 100.00 \\
\hline OPEX per barrel & $\mathrm{US} / \mathrm{Bbl}$ & & 3.00 & 3.00 & 3.00 & 3.00 & 3.00 & 3.00 & 3.00 & 3.00 & 3.00 & 3.00 & 3.00 & 3.00 & 3.00 & 3.00 & 3.00 & 3.00 & 3.00 & 3.00 & 3.00 & 3.00 & 3.00 \\
\hline Depreciation & $\%$ & $10 \%$ & & & & & & & & & & & & & & & & & & & & & \\
\hline TAX rate & $\%$ & $34 \%$ & & & & & & & & & & & & & & & & & & & & & \\
\hline WACC & $\%$ & $12 \%$ & & & & & & & & & & & & & & & & & & & & & \\
\hline RISKS INPUTS & & & \multicolumn{3}{|c|}{$\%$ Range } & \multicolumn{2}{|c|}{ Rate } & \multicolumn{2}{|c|}{ Probability } & & & & & & & & & & & & & & \\
\hline & & & Minimum & Mean & Maximum & Old & New & Old & New & & & & & & & & & & & & & & \\
\hline Utilization ( 90 or $100 \%$ ) & $\%$ & & & & & $90 \%$ & $100 \%$ & $100 \%$ & $0 \%$ & & & & & & & & & & & & & & \\
\hline Overbudget CAPEX & $\%$ & 0,00 & $-10 \%$ & $0 \%$ & $10 \%$ & & & & & & & & & & & & & & & & & & \\
\hline Overbudget OPEX & $\%$ & 0,00 & $-10 \%$ & $0 \%$ & $10 \%$ & & & & & & & & & & & & & & & & & & \\
\hline WACC (Spread) & $\%$ & $0 \%$ & & & $0 \%$ & & & & & & & & & & & & & & & & & & \\
\hline Utilization (draft) & & & $90 \%$ & $90 \%$ & $90 \%$ & $90 \%$ & $90 \%$ & $90 \%$ & $90 \%$ & $90 \%$ & $90 \%$ & $90 \%$ & $90 \%$ & $90 \%$ & $90 \%$ & $90 \%$ & $90 \%$ & $90 \%$ & $90 \%$ & $90 \%$ & $90 \%$ & $90 \%$ & $90 \%$ \\
\hline \multicolumn{24}{|l|}{ CALCULATIONS } \\
\hline Volume & MM US\$ & & 90.00 & 90.00 & 90.00 & 90.00 & 90.00 & 90.00 & 90.00 & 90.00 & 90.00 & 90.00 & 90.00 & 90.00 & 90.00 & 90.00 & 90.00 & 90.00 & 90.00 & 90.00 & 90.00 & 90.00 & 90.00 \\
\hline Margin ( $90 \%$ Utillization) & $\mathrm{US} \$ / \mathrm{Bbl}$ & & 5.00 & 5.00 & 5.00 & 5.00 & 5.00 & 5.00 & 5.00 & 5.00 & 5.00 & 5.00 & 5.00 & 5.00 & 5.00 & 5.00 & 5.00 & 5.00 & 5.00 & 5.00 & 5.00 & 5.00 & 5.00 \\
\hline Margin (100\% Utilization) & US\$/Bbl & & 1.00 & 1.00 & 1.00 & 1.00 & 1.00 & 1.00 & 1.00 & 1.00 & 1.00 & 1.00 & 1.00 & 1.00 & 1.00 & 1.00 & 1.00 & 1.00 & 1.00 & 1.00 & 1.00 & 1.00 & 1.00 \\
\hline Margin $(5$ or 1$)$ & US\$/Bbl & & 5.00 & 5.00 & 5.00 & 5.00 & 5.00 & 5.00 & 5.00 & 5.00 & 5.00 & 5.00 & 5.00 & 5.00 & 5.00 & 5.00 & 5.00 & 5.00 & 5.00 & 5.00 & 5.00 & 5.00 & 5.00 \\
\hline Capex Total & MM US\$ & & 20.00 & 20.00 & 20.00 & 20.00 & 20.00 & 20.00 & 20.00 & 20.00 & 20.00 & 20.00 & 20.00 & 20.00 & 20.00 & 20.00 & 20.00 & 20.00 & 20.00 & 20.00 & 20.00 & 20.00 & 20.00 \\
\hline Opex Total & MM US\$ & & 370.00 & 370.00 & 370.00 & 370.00 & 370.00 & 370.00 & 370.00 & 370.00 & 370.00 & 370.00 & 370.00 & 370.00 & 370.00 & 370.00 & 370.00 & 370.00 & 370.00 & 370.00 & 370.00 & 370.00 & 370.00 \\
\hline Depreciation & MM US\$ & 0 & 20.00 & 22.00 & 24.00 & 26.00 & 28.00 & 30.00 & 32.00 & 34.00 & 36.00 & 38.00 & 20.00 & 20.00 & 20.00 & 20.00 & 20.00 & 20.00 & 20.00 & 18.20 & 18.02 & 18.00 & 18.00 \\
\hline \multicolumn{24}{|l|}{ CASH FLOW } \\
\hline Revenue (Margin x Vol) & MM US\$ & & 450.00 & 450.00 & 450.00 & 450.00 & 450.00 & 450.00 & 450.00 & 450.00 & 450.00 & 450.00 & 450.00 & 450.00 & 450.00 & 450.00 & 450.00 & 450.00 & 450.00 & 450.00 & 450.00 & 450.00 & 450.00 \\
\hline Opex & MMUS\$ & & -370.00 & -370.00 & -370.00 & -370.00 & -370.00 & -370.00 & -370.00 & -370.00 & -370.00 & -370.00 & -370.00 & -370.00 & -370.00 & -370.00 & -370.00 & -370.00 & -370.00 & -370.00 & -370.00 & -370.00 & -370.00 \\
\hline EBITDA & MM USS & & 80.00 & 80.00 & 80.00 & 80.00 & 80.00 & 80.00 & 80.00 & 80.00 & 80.00 & 80.00 & 80.00 & 80.00 & 80.00 & 80.00 & 80.00 & 80.00 & 80.00 & 80.00 & 80.00 & 80.00 & 80.00 \\
\hline Depreciation & MM US\$ & & -20.00 & -22.00 & -24.00 & -26.00 & -28.00 & -30.00 & -32.00 & -34.00 & -36.00 & -38.00 & -20.00 & -20.00 & -20.00 & -20.00 & -20.00 & -20.00 & -20.00 & -18.20 & -18.02 & -18.00 & -18.00 \\
\hline EBITDA & MM USS & & 60.00 & 58.00 & 56.00 & 54.00 & 52.00 & 50.00 & 48.00 & 46.00 & 44.00 & 42.00 & 60.00 & 60.00 & 60.00 & 60.00 & 60.00 & 60.00 & 60.00 & 61.80 & 61.98 & 62.00 & 62.00 \\
\hline Depreciation & MM US\$ & & 20.00 & 22.00 & 24.00 & 26.00 & 28.00 & 30.00 & 32.00 & 34.00 & 36.00 & 38.00 & 20.00 & 20.00 & 20.00 & 20.00 & 20.00 & 20.00 & 20.00 & 18.20 & 18.02 & 18.00 & 18.00 \\
\hline Tax & MM US\$ & & -20.40 & -19.72 & -19.04 & -18.36 & -17.68 & -17.00 & -16.32 & -15.64 & -14.96 & -14.28 & -20.40 & -20.40 & -20.40 & -20.40 & -20.40 & -20.40 & -20.40 & -21.01 & -21.07 & -21.08 & -21.08 \\
\hline Working Capital & MM US\$ & & & & & & & & & & & & & & & & & & & & & & \\
\hline CASH FLOW Op & MM USs & & 59.60 & 60.28 & 60.96 & 61.64 & 62.32 & 63.00 & 63.68 & 64.36 & 65.04 & 65.72 & 59.60 & 59.60 & 59.60 & 59.60 & 59.60 & 59.60 & 59.60 & 58.99 & 58.93 & 58.92 & 58.92 \\
\hline Investiments & MM US\$ & & -20.00 & -20.00 & -20.00 & -20.00 & -20.00 & -20.00 & -20.00 & -20.00 & -20.00 & -20.00 & -20.00 & -20.00 & -20.00 & -20.00 & -20.00 & -20.00 & -20.00 & -20.00 & -20.00 & -20.00 & -20.00 \\
\hline CASH FLOW & MM US\$ & & 39.60 & 40.28 & 40.96 & 41.64 & 42.32 & 43.00 & 43.68 & 44.36 & 45.04 & 45.72 & 39.60 & 39.60 & 39.60 & 39.60 & 39.60 & 39.60 & 39.60 & 38.99 & 38.93 & 38.92 & 38.92 \\
\hline NPV & MMUSS & & 350.49 & & & & & & & & & & & & & & & & & & & & \\
\hline
\end{tabular}

The sensitivity analysis reveals that the price of imported oil has the highest impact in the cash flow, making EMV to range from US\$ 141.45 to 553.11 million, and EUV $(\alpha=$ 0.5 ) from 0.07 to 0.24 .

\section{CONCLUSION}

There are lots of studies that try to quantify the political and regulatory risks in the oil industry. In this paper we analyzed case studies of exploration and production $(\mathrm{E} \& \mathrm{P})$ 
and refining in Latin America to evaluate the effects of theses risks and compare different methods for calculating them.

There is a debate if political and regulatory risks should be incorporated directly in the cash flow or in the WACC equation. Although these risks can be considered market risks (i.e. have the potential to affect the whole economy) and should be quantified in the WACC equation, our findings indicate that considering these risks in the cash flow produces more consistent results and allows better risk analysis.

We evaluated four types of political and regulatory risks (price controls in E\&P, nationalism in E\&P via increased royalties, nationalism in $\mathrm{E} \& \mathrm{P}$ via expropriation, and refining risk via lack of supply). We show that, in general, changes in oil rules cause only small increases in the country risk and beta (therefore in the WACC) but generate great volatility in the cash flow. Although the political and regulatory risks are considered market risk and should be quantified in the WACC equation, inserting these risks directly in the cash flow produce better results when compared to adding a spread in the WACC.

\section{CONFLICT OF INTEREST}

The authors confirm that this article content has no conflicts of interest.

\section{ACKNOWLEDGEMENTS}

Declared none.

\section{REFERENCES}

[1] Brealey R, Myers S, Allen F. Principles of corporate finance. $9^{\text {th }}$ ed. NJ: John Wiley and Sons 2007.

[2] Damodaran A. Damodaran on Valuation. $2^{\text {nd }}$ ed. NJ: John Wiley and Sons 2006.

[3] Farber A, Gillet R, Szafarz A. A general formula for the WACC. Int J Bus 2006; 11: 405-11.

[4] Fernández P. A more realistic valuation: APV and WACC with constant book leverage ratio. J Appl Financ 2007; 17: 13-20.

[5] Jaeckel P. Monte carlo methods in finance. $1^{\text {st }}$ ed. New York: John Wiley and Sons 2002

[6] Glasserman P. Monte carlo methods in financial engineering. New York: Springer 2003.
[7] McLeish D. Monte Carlo simulation and finance. New York: Wiley 2005.

[8] Korn R, Korn E, Kroisandt G. Monte carlo methods and models in finance and insurance. London: Chapman \& Hall 2010.

[9] Motta R, Caloba G, Almeida L, et al. Investment and risk analysis applied to the petroleum industry. Proceedings of society of petroleum engineers asia pacific oil and gas conference; 2000 Oct 16-18; Brisbane, Australia; 2000.

[10] Suslick S, Schiozer D. Risk analysis applied to petroleum exploration and production: an overview. J Pet Sci Eng 2004; 44: $1-9$.

[11] Suslick S, Schiozer D, Rodriguez M. Uncertainty and risk analysis in petroleum exploration and production. Terræ 2008; 3: 36-47.

[12] Hailey W, Ryan E, Barnes C, Woodruff C. Strategic resources allocation processes and the use of quantitative methods in evaluation of plays in oil and gas exploration. Pet Account Financ Manag J 1992; 11: 78-95.

[13] Galli A, Armstrong M, Jehl B. Comparison of three methods for evaluating oil projects. J Pet Technol 1999; 10: 44-9.

[14] Orman M, Duggan T. Applying modern portfolio theory to upstream investment decision making. Proceedings of Society of Petroleum Engineers Annual Technical Conference; 1998 Sep 2730; Nero Orleans, Louisiana 1999.

[15] Razak R. Assessment of potential oil and gas exploration investments: management perspective. J Teknol 2001; 34: 25-38.

[16] Walls M. Combining decision analysis and portfolio management to improve project selection in the exploration and production firm. J Pet Sci Eng 2004; 44: 55-65.

[17] Erdogan M, Mudford B, Davidson J, Davis C. Managing risk in $\mathrm{E} \& \mathrm{P}$ industry though integrated portfolio management. Proceedings of the Istanbul 31st IAEE International Conference; 2008 June 18-20; Istanbul; Turkey 2008.

[18] Rodriguez J, Padua K. An application of portfolio optimization wit risk assessment to E\&P projects. Proceedings of the 2005 Crystal Ball User Conference; 2005 May; Denver: Colorado 2005.

[19] Arora S. Investment decision making in the upstream oil industry: an analysis 2012; Available at: http://ssrn.com/abstract=1983123

[20] Weber C. Quantification of political risk in energy foresight - a methods overview. EWL Working Paper No. 01/10. 2010.

[21] Merino R. What is 'post' in post-neoliberal economic policy? Extractive industry dependence and indigenous land rights in Bolivia and Ecuador 2011; Available at: http://ssrn.com/abstract= 1938677

[22] Haimes Y. Risk modeling, assessment and management. New York: Wiley 1998.

[23] Smith W. Criteria for strengthening buildings: cost-benefit analysis is misleading. Bull NZ Soc Earthquake Eng 2003; 36: 260-2.

[24] Friedman M, Savage L. The utility analysis of choices involving risk. J Polit Econ 1948; LVI: 279-304.

[25] Buhlmann H. An economic premium principle. ASTIN Bull 1980; 11: 52-60.

[26] Wang $S$ Equilibrium pricing transforms: new results using Buhlmann's 1990 economic model. ASTIN Bull 2003; 33: 57-73. 